\title{
DO EARED GREBES HAVE DUMP NESTS?
}

\section{By J. B. Gollop, Canadian Wildlife Service, Saskatoon}

On June 5, 1958, R. A. Lamont of Kindersley and the author examined the 1,600-acre "Redtop Slough", three miles north of Mantario, Saskatchewan. A twelve-foot aluminum cartop baat with an airthrust motor was used for the survey. The slough is divided by a peninsula of land from the north side into two parts, the west section being open and the east section being mostly covered with smartweed (Polygonum sp.). The smartweed reached a foot above the water. The water in most of the area examined in the east arm was about 24 inches deep, the maximum depth located being 54 inches.

Colonies of Franklin's Gulls and Eared Grebes were found. A complete census was noit attempted but a rough estimate of 1,000 nests of each species could easily be on the conservative side. An examination of twelve Franklin's Gull eggs indicated that the majority were one-third to two-thirds incubated. The more advanced Eared Grebe embryos had considerable feathering.

Several conglomerations of Eared Grebe eggs were noted. These were probably deposited and abandoned by a number of females. Unlike a somewhat similar situation in Redheads there was no nest under the eggs. Instead, they lay on the tangled vegetation between adjacent, ap- parently normal, nests which were about three feet apart. The eggs had apparently been added to the pile but many had moved down into the tangled vegetation or rolled off into the water. The eggs in two of these pyramid-like dumps were counted. Counting all the eggs above the water, submerged in the vegetation and on the slough bcttom in the immediate vicinity for about a foat, 101 eggs were found in the first dumping area and 94 in the second. It is doubtful whether all the eggs were found in either area. The first dump nest was between incubaited nests of 3 and 4 eggs in 24 inches of water. The second was surrounded by incubated nests of 5, 6 and 8 eggs in a depth of 21 inches.

The purpose of the trip was to investigate the prospects of Mallards moulting in the area. Possibly 3,000 4,000 flying drakes were seen -Pintails, Mallards and Shovelers being most abundant. A flock of nine, apparently non-breeding, Canada Geese were grazing on a crop on the east shore. Other species noted in numbers and apparently nesting were Redwinged Blackbirds and Yellow-headed Blackbirds, American Coots and American Avacets. There was no evidence of nesting waterfowl except for a Pintail hen acting as though she had a brood.

\section{GOLDEN EAGLE NESTING AT BEECHY, SASK.}

\section{By Dave Santy, Beechy, Sask.}

The South Saskatchewan River cuts deep through the Coteau Hills for sixty miles between Saskatchewan Landing and the Beechy ferry. The topography here is rough and rugged for over three miles back from the river on both sides, and these river breaks provide a home for the majestic Golden Eagle.

Although it breeds in this area, the Gclden Eagle does not seem to increase in numbers. I do not know of any other bird or animal that preys on it, and in this district eagles are not hunted or shot. It seems that eagles are not prolific breeders. Should the two eggs (the usual, number to a nest) hatch out, the stronger of the two young will likely, in time, kill the cther.

The Golden Eagle in this district usually nests on an outstanding peak or in a cleft in the face of a cliff. We have observed several nests throughout the years. Our most recent observation was made on June 29, 1958, with Frank Roy, who hoped to photograph the eagle. We tried to reach the eyrie on the side of an earth cliff in the river breaks south of Beechy. We were able to climb up only to the base of the big structure of sticks and earth. The bird continued throughout to sit on the nest, and hand-clapping and even small lumps of dirt thrown by us and land- 
ing on her back failed to budge her. She may have been covering young at the time.

We did not again visit the nest till mid-September when we found it vacated. Some earth had fallen into it from above. I can remember on a former occasion seeing a young bird that had perhaps been crowded out by earth falling into the nest being sheltered and cared for in a suitable shelter of rock at the bottom of the cliff.

As I have intimated, Mr. Roy and myself were unable to see the top of this nest at close quarters but the remains of rabbits were liberally strewn around the top of the hill. This nesit has been used regularly for the past five years. Other nests I have observed close-up had many remains of rabbits, gophers, weasels and carrion and had feathers of grouse and partridge. Eagles seem to have voracious appetiites.

EDITOR'S NOTE: Because nesting records for the Golden Eagle in Saskatchewan are rare, Mr. Santy and other readers will be interested in a histcrical account of the eagle nesting in northern Saskatchewan to be found in the Annual Report Geological Survey of Canada VIII (new series), 1895, part D, published 1896. On his 1892 expedition, Joseph Burr Tyrrell had the following note for August 11: "the river (Stone River, now called the Fond du Lac River) turns sharply from the south, arcund a sandstone hill on the east side of which is a beautiful cliff seventy feet high, where a pair of golden eagles (Aquila chrysaetos) have had a nest for a number of years." In his introductory remarks, Tyrrell previously stated that "a large golden eagle was shot beside its nest on a rocky cliff overlocking the Stone River."

\section{THE WASCANA CANADA GOOSE PROJECT, 1957-1958}

\section{By Fred G. Bard and Fred W. Lahrman, \\ Siaskatchewan Museum of Natural History}

The unusually fine weather in the winter of 1957-58 contributed to last spring's nesting success in the Wascana Waterfowl Park Goose project. Ninety-four Canada Geese came through the winter. Later the 1957 young left to "summer" away from the sanctuary. These same young returned a ferv days before the shocting season opened.

Nest building began the first week of April and the first young hatched on May 6. Nineteen pairs of geese brought off 46 young (from 11 nests). Two settings were donated to assist Abernethy and Eston parks. Six nests were destroyed by predators or through interference with the nesting birds. Sitting hens were used only when a goose deserted her nest. The young hatched by hens were introduced into the wild two days later.

Elevated nestis like those first used in Colorado experiments ware built in an attempt to overccme some of our losses. Of seven elevated nests made only one was used. It would appear that we placed them too close together and that they were much too high. We shall re-locate them this winter.

During the summer three adults died from flying into power lines or from unknown causes. A recent count showed 134 geese still in the park. We expected the birds to migrate this fall as frequent visits were made to stubble areas outside of the sanctuary, but they are still here (Oct. 31) and appear to be going to remain in the area. So farthe sportsmen in the Regina area have recognized the park geese and refrained from shooting them.

Occasionally other geese wander into the sanctuary. Late this fall a White-fronted Goose (Anser albifrons) lit among the Canada Geese and gave us an opportunity to observe it at close range.

A meeting of the Waterfowl Plark committee will be held in November to hear a park progress report and to discuss utilization, development, and future park plans.

Perhaps the most sericus problem cisnfronting our park is that of fluctuating water levels and marginal shoreline changes due to development through city expiansicn. Every growing city has similar problems, but Regina's is unique. The Waterfowl Park is an important part of our parks system and our needs musit be presented to those responsible for town planning in order to familiarize the various departments with cur needs.

In the Waterfowl Park this year it wras encouraging to note that after gravel was placed on Tern Island (to help build up and maintain this area) Common Terns returned to nest here. It's a small beginning but very encouraging. 